\title{
CBLB wt Allele
}

National Cancer Institute

\section{Source}

National Cancer Institute. CBLB wt Allele. NCI Thesaurus. Code C50389.

Human CBLB wild-type allele is located in the vicinity of 3q13.11 and is approximately 211 $\mathrm{kb}$ in length. This allele, which encodes E3 ubiquitin-protein ligase CBL-B protein, plays a role in protein degradation and the negative regulation of tyrosine kinase signaling pathways in the immune system. 